\title{
British America
}

Published for the Omohumdro Institute of Early American History and Culture, Williamsburg, Va.

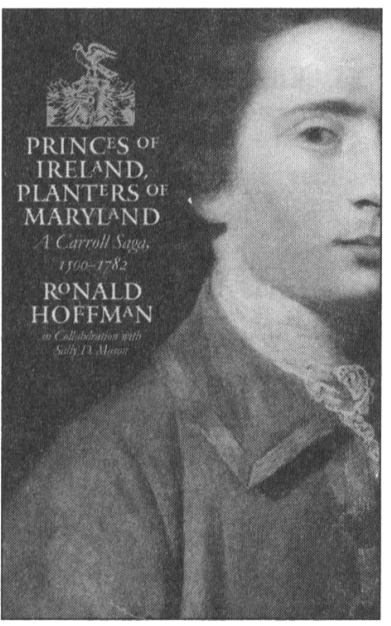

\section{PRINCES OF}

\section{IRELAND, PLANTERS OF MARYLAND}

A Carroll Saga, 1500-1782 RONALD HOFFMAN

In Collaboration with Sally D. Mason

"[This] extraordinary book is far more than a family biography. ... It reveals the human dimensions of Catholic/Protestant conflict on two continents." - Elaine Forman Crane, Fordham University

"A gripping read and a prime example of Atlantic history at its best."

- Nicholas Canny, National University of Ireland, Galway

"The most spectacular family saga ever in early American history. ... The fragility of the aristocratic project has never been better demonstrated." -Kenneth A. Lockridge, University of Montana

Approx. 480 pp., 21 illus., 6 genealogical charts $\$ 39.95$ cloth
THE PERSISTENCE

\section{OF EMPIRE}

British Political Culture in the Age of the American Revolution ELIGA H. GOULD

"A wide-ranging and highly intelligent exploration of why the American policies adopted by George III and his ministers were able to command wide support in Britain." - Linda Colley, European institute, London School of Economics

"Reevaluates the American Revolution as a defining moment in British history."-Richard Johnson, University of Washington

Approx. 288 pp., 29 illus.

$\$ 49.95$ cloth / \$18.95 paper

1993 Jamestown Prize, Institute of Early

American History and Culture

\section{NEW IN PAPERBACK!}

\section{THE LORD CORNBURY SCANDAL}

The Politics of Reputation in British America

\section{PATRICIA U. BONOMI}

"Historical detective writing at its best."-The Journal of American History "A fine piece of historical revisionism."

- Times Literary Supplement

"A model of historical investigation."

- New York Review of Books

304 pp., 46 illus. \$19.95 paper

1999 Society of Colonial Wars in the State of New York Book Award

\section{THE UNIVERSITY OF NORTH CAROLINA PRESS}

\author{
AT BOOKSTORES OR [800] 848-6224 | www.uncpress.unc.edu
}




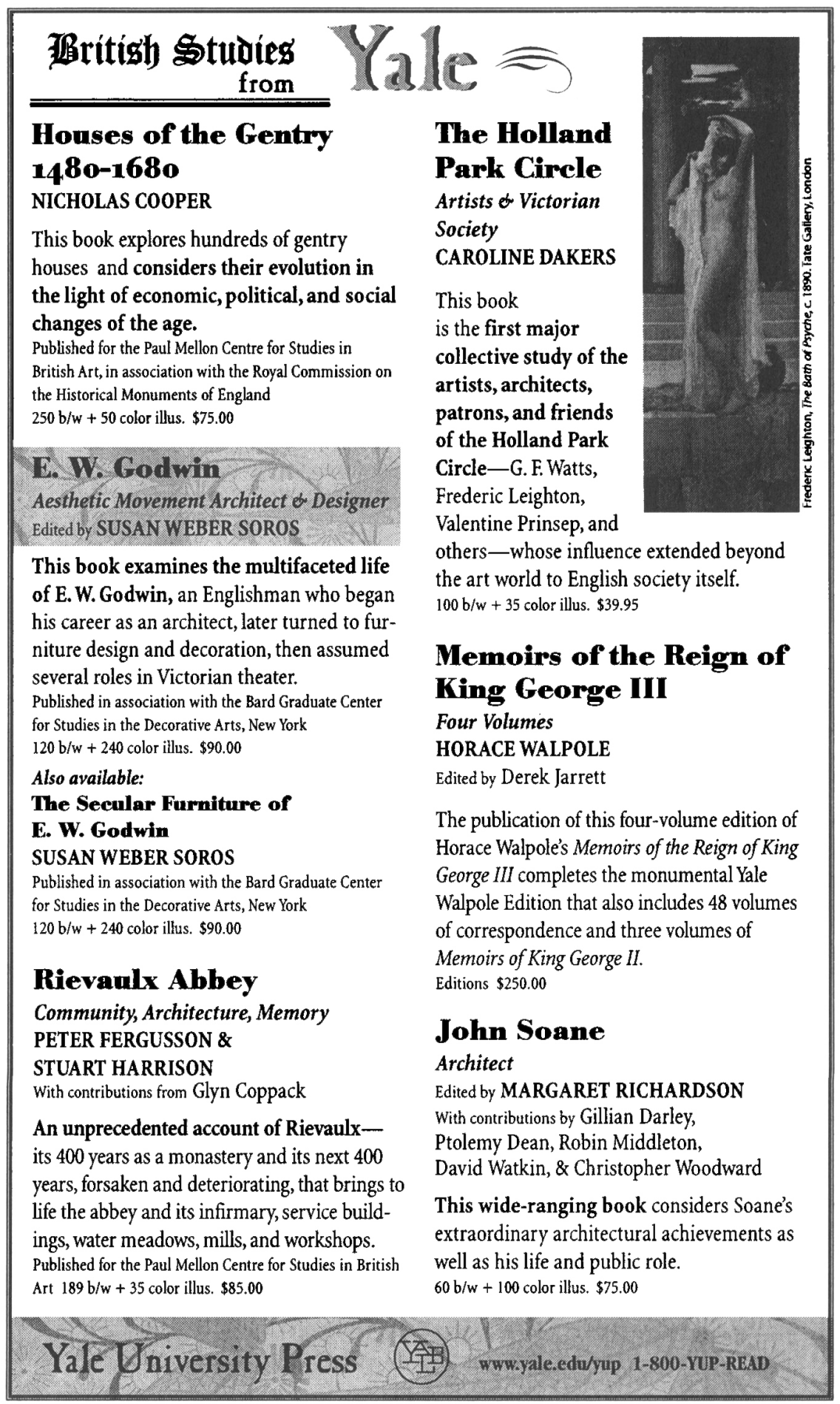




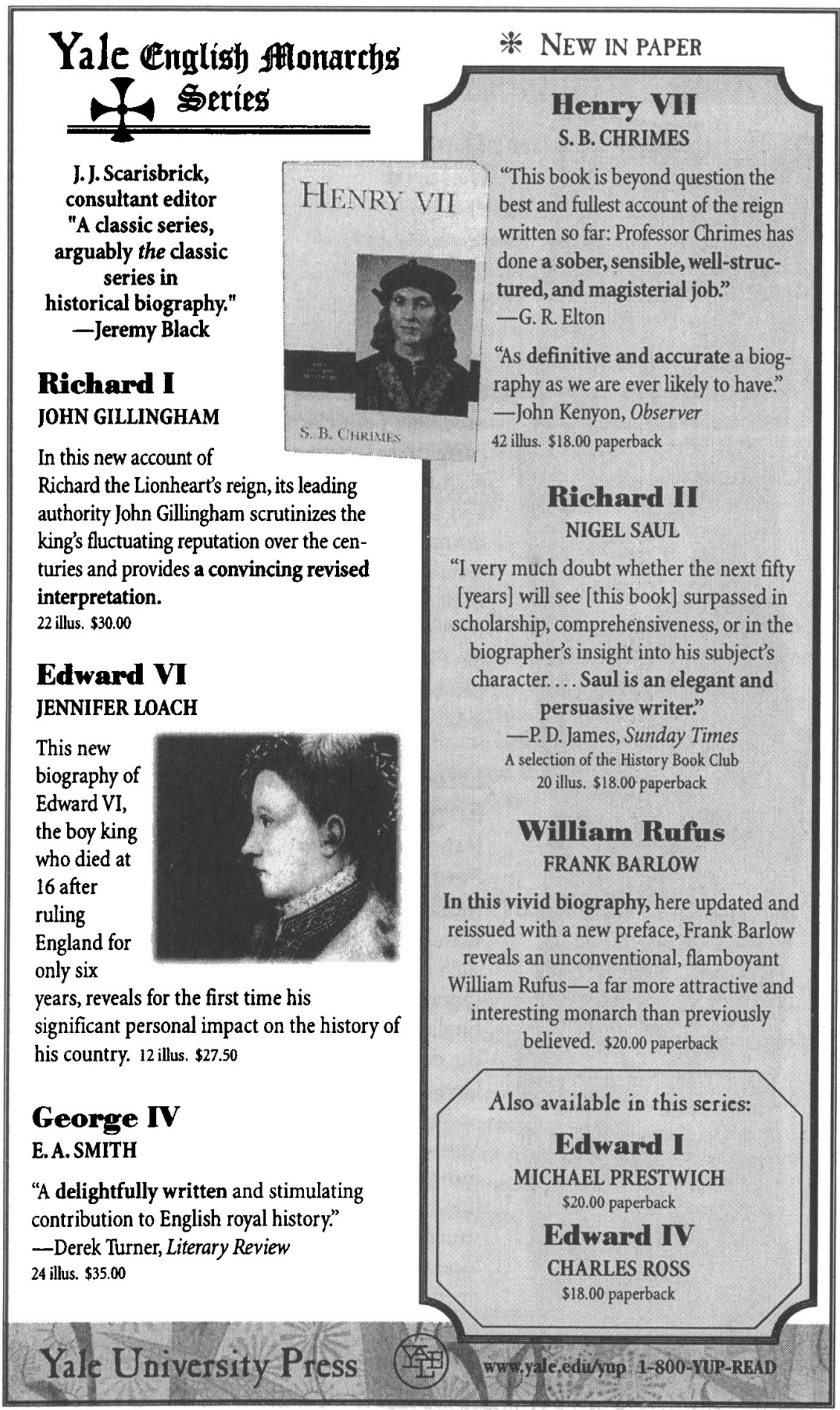




\section{NEW AND NOTEWORTHY}

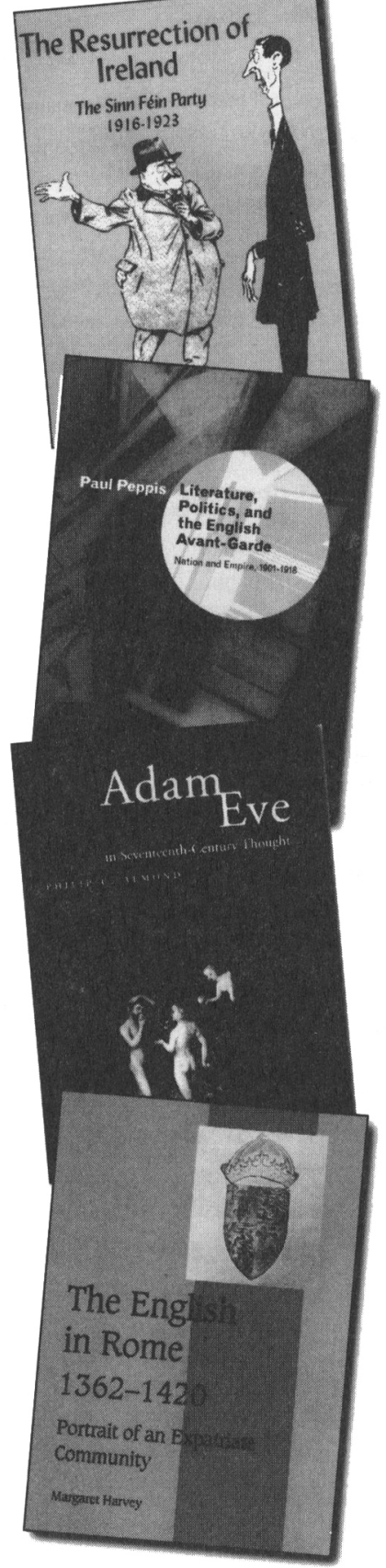

\section{The Resurrection of Ireland}

The Sinn Féin Party, 1916-1923

\section{Michael Laffan}

Between 1916 and 1923 Ireland experienced a political as well as a military revolution. This book examines how-after the Easter Rising of 1916-radical revolutionaries formed a precarious coalition with (relatively) moderate politicians. The new Sinn Féin party routed its enemies, cooperated uneasily with the underground Irish government, and achieved most of its objectives before disintegrating in 1922. Its rapid collapse should not distract from its achievementsin particular its role in "democratizing" the Irish revolution-while its successors since have dominated the political life of independent Ireland.

0-521-65073-9 Hardback \$69.95

\section{Literature, Politics and the English Avant-Garde}

Nation and Empire, 1901-1918

\section{Paul Peppis}

In Literature, Politics and the English AvantGarde, Paul Peppis reads texts by writers such as Ford Madox Ford, Wyndham Lewis, Dora Marsden, and Ezra Pound alongside English political discourse produced between the death of Victoria and the end of the Great War. He traces the impact of nation and empire on the avant-garde, arguing that Vorticism, England's foremost avant-garde movement, used nationalism to advance literature and avant-garde literature to advance empire. By recovering these neglected aspects of avant-garde politics, Peppis' book opens important new avenues for assessing modernist politics after the war.

0-521-66238-9 Hardback \$59.95 


\section{From Cambridge}

\section{Adam and Eve in Seventeenth-Century Thought Philip C. Almond}

This book offers a fascinating account of the central myth of Western culturethe story of Adam and Eve in the Garden of Eden. Philip Almond examines the way in which the gaps, hints, and allusions within the Biblical story were filled out in seventeenth-century English thought. He creates a picture not only of the mainstream and marginal theological and philosophical readings of the Edenic tradition, but also of its central role in most of the major intellectual issues of seventeenth-century English life, both religious and secular.

0-521-66076-9 Hardback \$54.95

\section{The English in Rome, 1362-1420}

Portrait of an Expatriate Community

Margaret Harvey

Centered on a study of the early archives of the Venerabile Collegio Inglese in Rome, this book attempts to place in its political, commercial and religious setting the English community that was in Rome between 1362, when the first English hospice for poor people and pilgrims was founded, and 1420. The book also uncovers a notable, although unsuccessful, attempt to forward English participation in commerce with Rome before 1420, revealing important links between the English laity in Rome and the city of London.

Cambridge Studies in Medieval Life and Thought: Fourth Series 45

0-521-62057-0 Hardback \$59.95

\section{Restoration and Reform, 1153-1165}

Recovery from Civil War in England

\section{Graeme J. White}

This book, covering the close of Stephen's reign (1135-54) and the early phase of Henry II's (1154-89), examines the government of England in the aftermath of civil war. It suggests that the extent of "anarchy" under Stephen has been exaggerated and that there was much administrative continuity from one reign to the next. Previous studies of Henry II's government have often neglected his earliest years, but here there is a reassessment of the significance of financial and judicial measures during 1163-65, as "restoration" gave way to "reform." Cambridge Studies in Medieval Life and Thought: Fourth Series 46 0-521-55459-4 Hardback \$64.95 


\section{Journal of}

\section{Victorian Culture}

Volume 41999 ISSN 1355-5502

Two issues per year

Now in its fourth year, Joumal of Victorian Culture is essential reading for scholars of the Victorian period. It provides an international forum for discussion and debate on all aspects of Victorian history and culture in a diverse range of formats, including articles, perspectives, roundtables and a section of substantial reviews.

Journal of Victorian Culture is addressed to scholars working within the various disciplines which have traditionally constituted Victorian Studies:

$\begin{array}{ll}* & \text { Architectural history } \\ \text { Cultural studies } \\ \text { Thenomic and social history } \\ \text { Literary studies } \\ \text { Pusic } \\ \text { Theatre } \\ \text { The visual arts }\end{array}$

This exciting journal is required reading for anyone who seeks to keep abreast of developments in the contemporary understanding of Victorian society and culture, and will appeal both to scholars and to keen 'Victorianists' alike.

\section{Highlights}

Blindness and Insight: Millais' The Blind Girl and the limitations of representation (Kate Flint)

The sublime and the vulgar: the Hallé concerts and the constitution of 'high culture' in Manchester, c. 1850-1880 (Simon Gunn)

Coin and Country: visions of civilisation in the British recoinage debate, 1867-1891 (Timothy L Alborn)

Being in debt in Dickens' London: fact, fictional representation and the nineteenth-century prison (Margot Finn)

The English Face of Karl Marx (Miles Taylor) The Victorian Public Library (Alistair Black) Anthologising Women Poets (Virginia Blain)

Victorian Music: A Perspective (Cyril Ehrlich and Dave Russell)

Roundtable: Darwin

(Lucy Hartley, Pietro Corsi, Ted Benton, James Moore and Adrian Desmond)

Roundtable: City of Dreadful Delight (Martin J Wiener, John Stokes, Sally Alexander, Judith $R$ Walkowitz)

Roundtable: The V \& A: A Grand Design? (Charles Saumarez Smith, Giles Waterfield, Tim Barringer, Malcolm Baker)

Please enter my subscription to the Joumal of Victorian Culture, Vol. 4 at the rate indicated:
Institutions
$\square$ UK and EC
口 N. America
E40.00 UK and EC
$\$ 80.00$
Q N. America
a Rest of World $£ 45.00$
$\square$ Please send me a free sample copy

Name

Postcode

Country

\section{Order Form}

I enclose a cheque made payable to

Edinburgh University Press Ltd

D Please debit my Visa/MasterCard

Card number

Expiry date

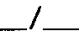

Signature 


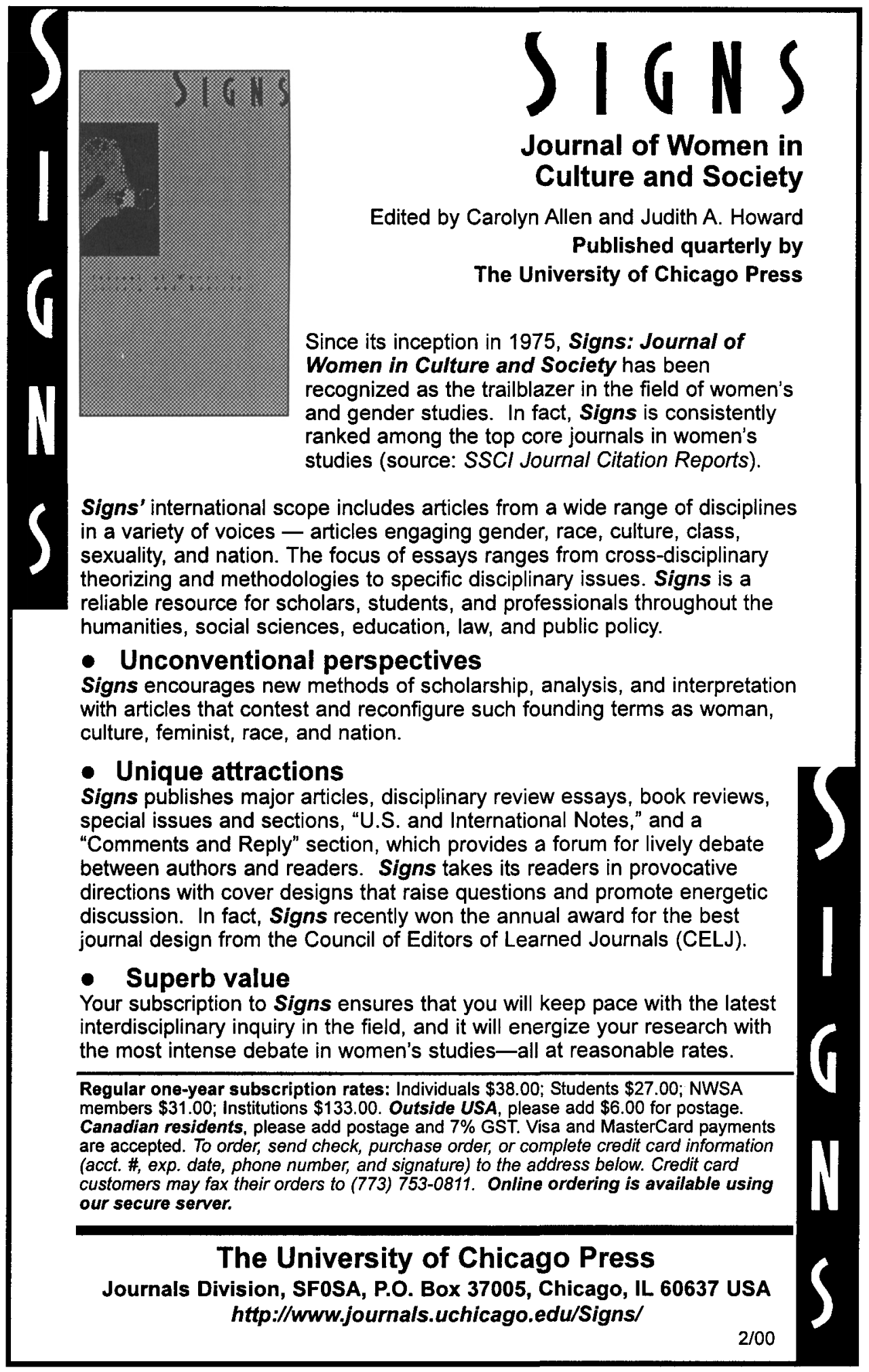




\section{JOURNAL \\ 口OF THE口 \\ HISTORY OF \\ SEXUALITY}

\section{Barbara Loomis and William Bonds, Editors}

Established in 1990, JHS illuminates the history of sexuality in all its expressions, recognizing various differences of class, culture, gender, race, and sexual orientation. Its cross-cultural and cross-disciplinary character brings together

original articles and critical reviews from historians, social scientists, and humanities scholars worldwide.

\section{January 2000, Volume 9, Number 1}

Self-Pollution, Moral Reform and the Venereal Trade: Notes on the Sources and Historical Context of the Onania (1716)

\section{Micheal Stolberg}

"Strong Animal Passions" in the Gilded Age: Race, Sex and a Senator on Trial

Lynn Hudson

Bathhouses, Hustlers and a Sex Club: The Reception of Mikhail Kuzmin's Wings

John E. Malmstad

Nakedness, Non-Violence and Brahmacharya: Gandhi's Experiments in Celibate Sexuality

Vinay Lal

Subscription Rates:

Individuals $\$ 41$, Institutions $\$ 115$, Canada/Mexico $\$ 12$, Other foreign add $\$ 22$. Single Copy Rates:

Individuals $\$ 15$, Institutions $\$ 32$, Mexico/Canada $\$ 3$, Other foreign, add $\$ 5.50$.

\section{University of Texas Press, Journals Division,}

Box 7819, Austin,Texas 78713-7819

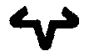




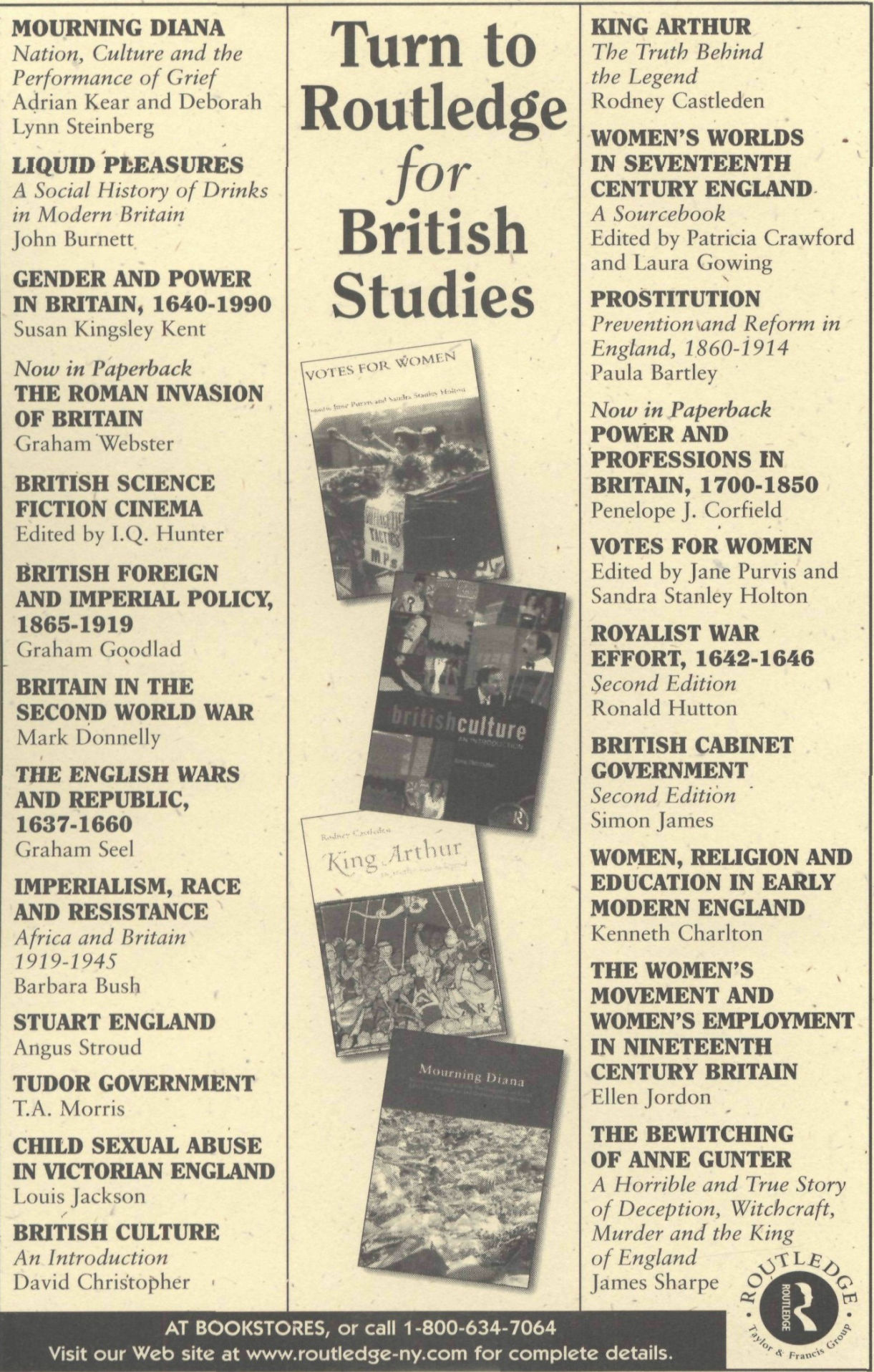




\section{The University of \\ C h i c a g o Press \\ Journals and Annual Series}

American Journal of Education

D The American Journal of Human Genetics

$\square$ American Journal of Sociology online in 2000

$\square$ The American Naturalist

ㅁ The Astronomical Journal

․ The Astrophýsical Journal

$\square$ The Astrophysical Journal Supplement Series Classical Philology

口 Clinical Infectious Diseases Comparative Education Review Crime and Justice Critical Inquiry

므 Current Anthropology

Economic Development and Cultural Change

The Elementary School Journal Ethics; An International Journal of Social, Political, and Legal Philosophy

History of Religions

International Journal of American Linguistics

ㅁ International Journal of Plant Sciences

Isis

Journal of the American

Musicological Society

Journal of British Studies

The Journal of Business

ㅁ Journal of Consumer Research:

An Interdisciplinary Quarterly

online in 2000 $\square \quad$ The Journal of Geology

ㅁ. The Journal of Infectious

\section{Diseases}

Journal of Labor Economics

The Journal of Law \&

Economics

- The Journal of Legal Studies

ㅁ. The Journal of Modern History online in 2000

Journal of Near Eastern Studies

口 Journal of Political Economy online in 2000

The Journal of Religion

Law \& Social Inquiry

The Library Quarterly

Modern Philology

Ocean Yearbook

Osiris

Philosophy of Science

פ Physiological and Biochemical Zoology

ㅁ Public Opinion Quarterly online in 2000

$\square$ Publications of the Astronomical Society of the Pacific

The Quarterly Review of Biology

Signs: Journal of Women in Culture and Society

Social Service Review

Supreme Court Economic Review

The Supreme Court Review

Winterthur Portfolio

Electronic editions availablè

\section{The University of Chicago Press journals Division: P.O. Box 37005 \\ Chicago, 11.6063 T USA \\ Phone 773.753 .3347 Irax 773 . 53.0811 .

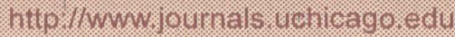

